\title{
Effect of Length of External Bar at Soffit on the Performance of Retrofitted RC Beams - A Finite Element Study
}

\author{
G. Vasudevan ${ }^{\mathrm{a}, 1}$ and S. Kothandaraman ${ }^{\mathrm{b}, 2}$ \\ a Perunthalaivar Kamarajar Institute of Engineering and Technology, Karaikal, India \\ ${ }^{\mathrm{b}}$ Pondicherry Engineering College, Puducherry, India \\ 11vasug1967@gmail.com \\ 2 skramane@gmail.com
}

УДК 539.4

\section{Конечноэлементный расчет влияния длины внешнего потолочного бруса на работоспособность модифицированных железобетонных перекрытий}

\author{
Г. Васудеван ${ }^{\mathrm{a}}$, С. Котандараман ${ }^{6}$ \\ ${ }^{a}$ Институт машиностроения и технологий им. Перунталаивара Камараджара, Карайкал, Индия \\ ${ }^{\sigma}$ Инженерный колледж Пондичерри, Пондичерри, Индия
}

Представлены результаты конечноэлементного расчета прогиба модифицированных железобетонных перекрытий с учетом влияния длины внешнего потолочного бруса. С помощью программного пакета ANSYS 12.0 выполнен расчет напряженно-деформированного состояния пяти образцов модифицированных железобетонных перекрытий, усиленных внешним брусом различной длины, и тарировочного образиа. Исследованы процессы зарождения трещин, поведение перекрытий при пластической деформации внутреннего бруса и на стадии разрушения, а также закономерности формирования и распространения трещин.

Ключевые слова: модификация перекрытий, внешний брус, длина бруса, потолок, ANSYS.

Introduction. Retrofitting of reinforced concrete $(\mathrm{RC})$ beams is one of the essential requirements of $\mathrm{RC}$ buildings in order to take care of increased seismic forces due to codal revisions; increased loading requirements due to functional change; extend the life of buildings vulnerable to natural disasters. Though the techniques such as beam jacketing, bonded steel plating, external post-tensioning and FRP wrapping are widely adopted for the retrofitting of structural elements, they have limitations such as high cost, loss of aesthetics, increase in self-weight, need for careful surface preparation, unexpected delamination failure, etc. The external reinforcement technique, proposed by the authors $[1,2]$ can be adopted as one of the cost effective and easy-to-use flexural retrofitting technique due reasons such as use of cost effective materials; speed and simplicity of installation; minimal disruption during installation; minimal surface preparation of concrete substrate; no de-lamination failure problems, as experienced in bonded plates and FRP laminates. Results of the non-linear finite element analysis (NLFEA) of a reference beam specimen and five numbers of retrofitted beam specimens with external bars at the soffit with varying length were carried out and the results are discussed. Heterogenic and cracking behavior of concrete beam and unusual behavior of external bars due to absence of proper bonding has been modeled using Solid65, Solid45, Link8, and Combin39 elements. 
1. Review of Literature. Dahmani et al. [3] studied the crack propagation in RC beams using ANSYS with smeared reinforcement approach, in which, the concrete and the reinforcing bars were incorporated into the concrete elements with the same geometrical boundaries and the effects of reinforcing bars were averaged within the pertaining concrete element. Hawileh et al. [4] developed a 3D FE model to simulate the performance of RC beams externally strengthened with short-length CFRP plates. The different material nonlinear constitutive laws including the bond-slip action between steel rebars and surrounding concrete and debonding at the CFRP-concrete interface were incorporated in the model. Bennegadi at al. [5] developed a numerical model using ANSYS for the optimization of the external reinforcement of RC beams by hybrid fiber reinforced polymer (HFRP) plate. Static nonlinear analysis was done to find the out ultimate capacity, formation of first crack, initiation of diagonal crack and its distance from the edges of HFRP plate. Parametric study also made to evaluate both effects of height and width of the HFRP plate on the retrofitted beam. Rousan and Haddad [6] developed a NLFEA model to predict the contribution of FRP composites in regaining structural performance and controlling failure of shear-deficient and sulfate-damaged RC beams. The performance was evaluated using ultimate shear strength, stiffness, toughness, and crack-opening toughness. Aktas and Sumer [7] conducted FE analysis of seven RC beams to validate the modeling strategies by comparing the structural response of the beams. Three beams in the set were pre-damaged and strengthened with FRC before the bending tests. Cracks were implemented into the model by inserting geometrical discontinuities to represent the pre-damaged beams. Parametric variables such as crack width, length and interval were chosen to simulate different pre-damage levels to study the effects of pre-damage levels on the moment capacity of RC beams repaired with CFRP. Their results indicated that inclusion of pre-damage levels by means of cracks into the cross sections have significant effect on beams moment capacity. A three-dimensional FE model was developed by Sayed et al. [8] to study the effects of beam width, the concrete strength, the height and thickness of the FRP sheet, the elastic modulus of the FRP and the strengthening configuration (complete wrapping, U-jacketing, and side bonding) on the failure modes and ultimate shear capacity of RC beams strengthened with FRP sheets. The authors [9] carried out NLFEA of bearing capacity of RC beams retrofitted with external bars at soffit using ANSYS software and validated with experimental results of twenty numbers of beam specimens under four-point bending. Study on flexural retrofitting of RC beams using external bars with additional intermediate anchorages at soffit was also carried out by the authors [10]. It was found that external bars at soffit with two end anchorages performed effectively when compared with external bars with additional intermediate anchorages due to loss of tied-arch action. Zidani et al. [11] presented an advanced FE model using ANSYS to simulate the flexural behaviour of initially damaged concrete beams repaired with FRP plates. The model was capable to simulate the full history stages; where the beam was initially loaded to introduce damage, then, after bonding the FRP plates, the beam was reloaded up to failure. FE simulation of debonding failures in FRP-strengthened concrete beams were carried out by Chen et al. [12]. They examined the effectiveness of using a dynamic analysis approach in such FE simulations, in which debonding failure was treated as a dynamic problem and solved using an appropriate time integration method to overcome the convergence problem. Almassri et al. [13] investigated corroded RC beams repaired with near surface mounted (NSM) CFRP rods and studied the failure mode of the repaired beam by experimental and numerical modelling using FEMIX computer code on five, 3-m-long beams (three corroded RC beams that had been exposed to natural corrosion for 25 years and two control beams with no corrosion). Teng et al. [14] presented a new strength model for end cover separation failure in RC beams strengthened in flexure with NSM FRP strips. The model was formulated on the basis of an efficient FE approach, which uses an approximate equation for the debonding strain of the FRP reinforcement at 
the critical cracked section and a conventional section analysis to relate this debonding strain to the moment acting on the same section. Pathak et al. [15] investigated the structural behavior of FRP strengthened RC beams by developing a new simple, efficient and accurate finite element model (FEM-B) considering FRP, concrete and steel rebars, the adhesive and stirrups. The initial finite element model (FEM-P) was developed assuming a perfect bond between concrete, FRP and adhesive interfaces and expanded to form the FEM-B model by including the bond-slip effect between concrete, FRP and adhesive interfaces.

2. Beam Specimens Considered for the Study. A control beam specimen (RF-N-10) and five numbers of retrofitted beam specimens (ER-N-10-10, ER-N-10-10-L1, ER-N-10-10-L2, ER-N-10-10-L3, ER-N-10-10-L4) with varying external bar length at the soffit were used for the FE analysis. Details and arrangement of external bars, anchorage procedures etc., were presented in detail in the earlier literature of the authors [9]. The FE results of the reference beam specimen (RF-N-10) and one of the retrofitted beam specimens (ER-N-10-10) were compared and discussed with experimental results and presented in earlier article [10]. The overall size of the specimen is $2000 \times 250 \times 200 \mathrm{~mm}$ with an effective span of $1800 \mathrm{~mm}$. Effective cover of $31.25 \mathrm{~mm}$ was used for the FE modeling. The beam specimens were analysed for four-point bending with loading at a distance of $550 \mathrm{~mm}$ from either end of the support, so as to have a moment span of $700 \mathrm{~mm}$. The beam specimens were provided with steel reinforcements of 2 numbers of $10 \mathrm{~mm}$ dia. (area $=157 \mathrm{~mm}^{2}$ ) with yield strength of $556 \mathrm{MPa}$ at bottom (internal bars), top (compression bars) and as external bars. The details, other parameters and length of external bars used are shown in Fig. 1 and Table 1.

$\mathrm{T}$ a b 1 e 1

Details of Beam Specimens

\begin{tabular}{|c|c|c|c|c|c|c||}
\hline No. & Beam ID & $\begin{array}{c}\text { Beam size } \\
(\mathrm{mm})\end{array}$ & $\begin{array}{c}\text { Compressive } \\
\text { strength } \\
f_{c k}, \mathrm{MPa}\end{array}$ & $\begin{array}{c}\text { Modulus } \\
\text { of rupture } \\
f_{c r}, \mathrm{MPa}\end{array}$ & $\begin{array}{c}\text { Elastic } \\
\text { modulus } \\
E_{t}, \mathrm{MPa}\end{array}$ & $\begin{array}{c}\text { Length } \\
\text { of external } \\
\text { bar }(\mathrm{mm})\end{array}$ \\
\hline 1 & RF-N-10 & $200 \times 250$ & 35.6 & 4.18 & 29,833 & - \\
\hline 2 & ER-N-10-10 & $200 \times 250$ & 38.2 & 4.33 & 30,903 & 1650 \\
\hline 3 & ER-N-10-10-L1 & $200 \times 250$ & 38.2 & 4.33 & 30,903 & 1350 \\
\hline 4 & ER-N-10-10-L2 & $200 \times 250$ & 38.2 & 4.33 & 30,903 & 1000 \\
\hline 5 & ER-N-10-10-L3 & $200 \times 250$ & 38.2 & 4.33 & 30,903 & 600 \\
\hline 6 & ER-N-10-10-L4 & $200 \times 250$ & 38.2 & 4.33 & 30,903 & 200 \\
\hline
\end{tabular}

Note: $f_{c r}=0.7\left(f_{c k}\right)^{1 / 2}$ and $E_{t}=5000\left(f_{c k}\right)^{1 / 2}[16]$.

3. Finite Element Modeling and Analysis Using ANSYS. The concrete elements were modeled using SOLID65 element with three degrees of freedom at each node (translations in the nodal $x, y$, and $z$ directions), capable of handling nonlinear cracking behavior in three orthogonal directions due to tension, crushing in compression and plastic deformation. The reinforcing bars were incorporated in the concrete model using two noded LINK8 spar element with three degrees of freedom at each node (translations in the nodal $x, y$, and $z$ directions), capable of handling plasticity, creep, swelling, stress stiffening and large deflection. The supports and loading points were incorporated as steel cushion using eight noded SOLID45 element with three degrees of freedom at each node (translations in the nodal $x, y$, and $z$ directions) to avoid problems of stress concentration. 


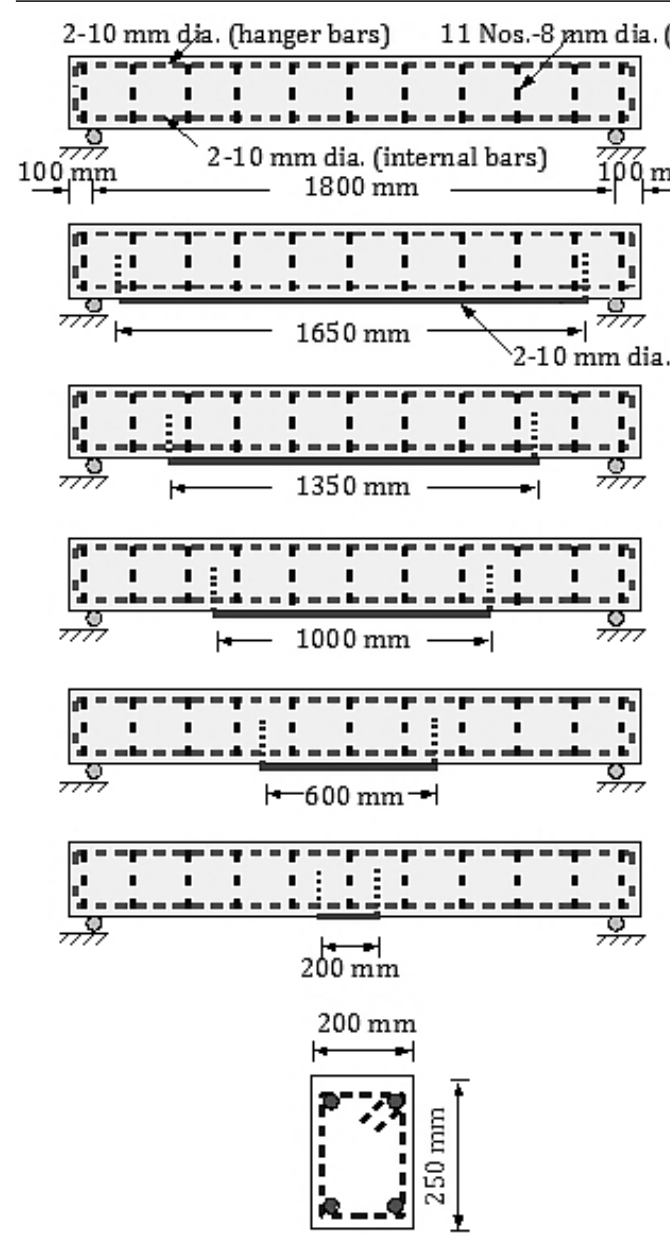

Cross section of reference beam

Beam specimen details

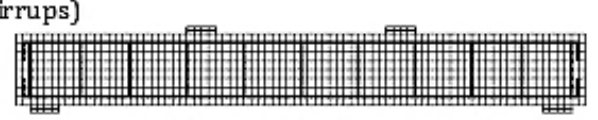

RF-N-10

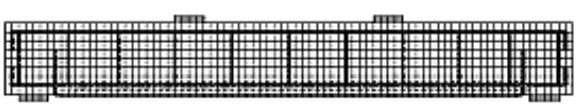

ER-N-10-10

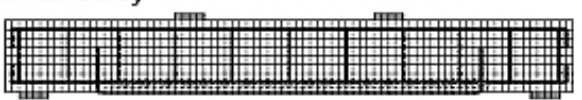

ER-N-10-10-L1

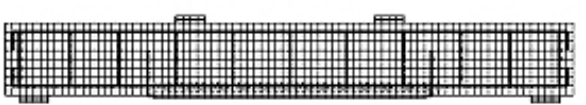

ER-N-10-10-L2

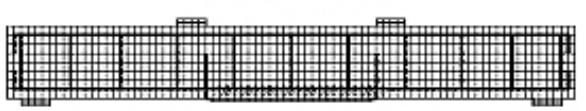

ER-N-10-10-L3

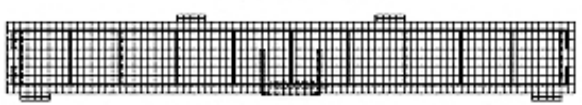

ER-N-10-10-L4

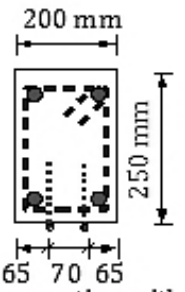

Cross section with additional external bars

Beam specimen FEA models

Fig. 1. Details of beam specimen and FEA models.

The contact between external bars and the soffit of the beam were incorporated using COMBIN39, a unidirectional element with nonlinear generalized force-deflection capability. Material model for concrete used for the study has been derived from IS 456 [16]. Other parameters used for the modeling is furnished in Table 2. The steel reinforcement used for the models was assumed to be an elastic-perfectly plastic material, identical in tension and compression. For the elastic range, elastic modulus of $200,000 \mathrm{~N} / \mathrm{mm}^{2}$ and Poisson's ratio of 0.2 was used to setup a linear isotropic model. For bilinear isotropic hardening model of LINK8 element, the stress-strain curve of reinforcement follows the specified yield stress and continues along the second slope defined by the tangent modulus. It was studied and suggested by earlier researchers [3] that a tangent modulus of 10 to $20 \mathrm{~N} / \mathrm{mm}^{2}$ is to be used to avoid loss of stability upon yielding and hence a value of $20 \mathrm{~N} / \mathrm{mm}^{2}$ was adopted in the present study. Other parameters were taken as program default. The FE modeling was carried out in batch mode in sequence using, KEYPOINTS, LINES, LESIZE, VOLUME, VMESH and VSWEEP commands. The rebar elements were introduced in the nodes of the concrete elements using discrete reinforcement modeling which is most preferred for $\mathrm{RC}$ 
$\mathrm{T}$ a b 1 e 2

Materials Properties for Concrete and Steel Used for the FE Modeling

\begin{tabular}{||l|c||}
\hline \multicolumn{1}{|c|}{ Property } & Value used \\
\hline Yield strength of hanger bars & $556 \mathrm{MPa}$ \\
\hline Yield strength of stirrups & $550 \mathrm{MPa}$ \\
\hline Tangent modulus for steel & $20 \mathrm{MPa}$ \\
\hline Poisson's ratio of concrete & 0.2 \\
\hline Shear transfer coefficient for open crack & 0.3 \\
\hline Shear transfer coefficient for closed crack & 1.0 \\
\hline Uniaxial crushing stress value & -1.0 \\
\hline Stiffness multiplier constant $(T c)$ & 0.6 \\
\hline
\end{tabular}

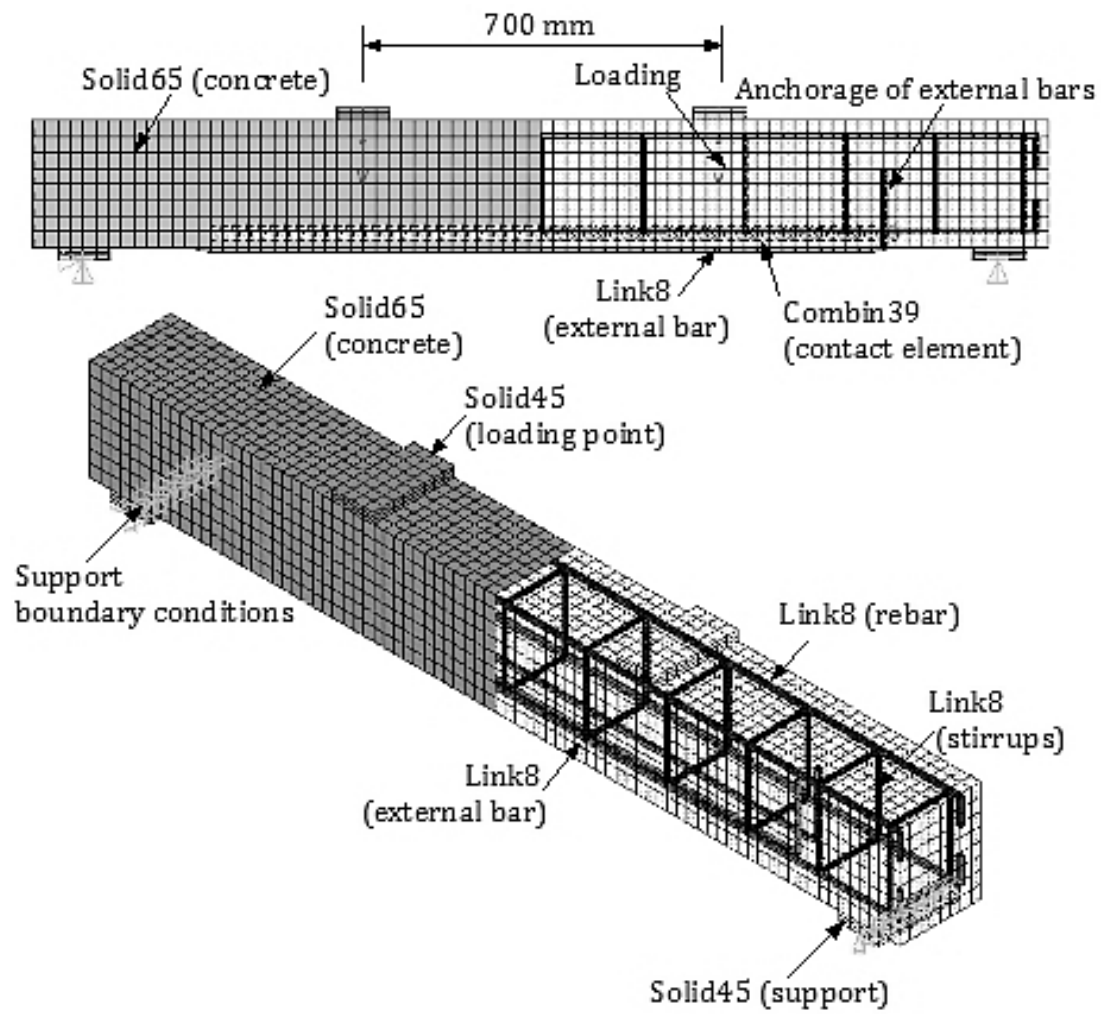

Fig. 2. Typical FEA model.

elements with well-defined reinforcement locations using E and EGEN commands. The support conditions were created using displacement (D) boundary conditions. The entire process of the non-linear finite element analysis such as geometrical modeling, material modeling, parameters for non-linear analysis, creation of load-steps, graphical post processing of results, generation of various graphs and images and output in the form of text file was generated using a single input file developed using the APDL. A typical FE model with discrete reinforcement model is shown in Fig. 2. The external reinforced beams behave in a hybrid of flexural and tied arch action with frictional bonding between the 
soffit of the beam and the external bars. The external bars also follow the deflected shape of the beam due to loading. These behaviors of the external bars were incorporated in the model by the use of COMBIN39 element between the external bar and the soffit of the beam. COMBIN39 is a unidirectional element with nonlinear generalized force-deflection capability. The element has longitudinal or torsional capability. The longitudinal option is a uniaxial tension-compression element with up to three degrees of freedom at each node such as translations in the nodal $x, y$, and $z$ directions. Displacement along $x$ and $y$ directions were activated for the longitudinal and transverse COMBIN39 spring elements and all other options were set to default values. For incorporating the frictional bonding of longitudinal COMBIN39 elements, $5 \%$ of the bond strength [9] of the fully bonded bar is assumed using IS 456 [16] codal values.

\section{Results and Discussion.}

4.1. Deflection Behavior. Deflection behavior of beams is one of the vital factors which determine the serviceability performance of any retrofitting technique. The deflection is a function of load, length of span, second moment of area and elastic modulus of material. The deflection at centre of midspan and loading points of the beams were recorded at every $5 \mathrm{kN}$ load increment and graphed as show in Fig. 3. The salient points (points $A$ to $J$ ) of the load versus midspan deflection curves are indicated in the graph for the reference beam specimens (RF-N-10-Test, RF-N-10-FEA) and retrofitted beam specimens (ER-N-10-10-Test, ER-N-10-10-FEA, ER-N-10-10-L1-FEA, ER-N-10-10-L2-FEA, ER-N-10-10-L3-FEA, ER-N-10-10-L4-FEA). The discussions presented in this paper are based on the comparison of the critical results obtained using the FE analysis. The experimental load-deflection curves of the reference beam specimen (RF-N-10-Test) and retrofitted beam specimen with maximum external bar length of $1650 \mathrm{~mm}$ (ER-N-10-10Test) is presented only for relative comparison with corresponding FEA results. As can be seen from the Fig. 3, the deflection behavior of the reference and the retrofitted beams are similar and closer to each other till the formation of initial crack $(A$ and $D)$. However, the initial cracking load for the retrofitted beam specimens ER-N-10-10, ER-N-10-10-L1, ER-N-10-10-L2 is marginally higher than the reference beam specimen. After the yielding of internal bars, the strength and the stiffness of the strengthened specimens ER-N-10-10, ER-N-10-10-L1, ER-N-10-10-L2 were larger up to the ultimate stage when compared to the reference beam (RF-N-10) specimens except ER-N-10-10-L3 and ER-N-10-10-L4. It is to be noted that the slope of the load-deflection curves of the retrofitted beam specimens ER-N-10-10 and ER-N-10-10-L1 after the yielding of internal bar are steeper than the corresponding reference beam specimen (RF-N-10), which indicates the increase in stiffness due to the addition of external bars at the soffit. However, retrofitted beams ER-N-10-10-L3 and ER-N-10-10-L4 shows almost no improvement in deflection behavior when compared to the reference beam specimen. The beam specimen ER-N-10-10-L2 shows average improvement in performance with respect to deflection behavior. Also for a particular load level, the deflections of the retrofitted beam specimens ER-N-10-10, ER-N-10-10-L1, ER-N-10-10-L2 are less than the respective reference beam specimens. For the above three retrofitted beam specimens, at any load level, the deflections are reduced significantly when compared to the reference beam specimen. Whereas, the deflection performance of the retrofitted beam specimen with smaller external bar length (ER-N-10-10-L3 with $600 \mathrm{~mm}$ and ER-N-10-10-L4 with $200 \mathrm{~mm}$ shows almost no improvement in deflection behavior when compared to the reference beam specimen.

4.2. Importance of External Bar Length on Deflection Behavior. When comparing the deflection curves of beams ER-N-10-10-L3 and ER-N-10-10-L4 with reference beam specimens, it is found that the provision of external bar of shorter length at midspan is of almost no use in improving the deflection control of the beam. Hence, the performance of the retrofitted beams with respect to length of external bar shows much improvement only when the length of external bar is longer (almost for the entire span of the beam). 

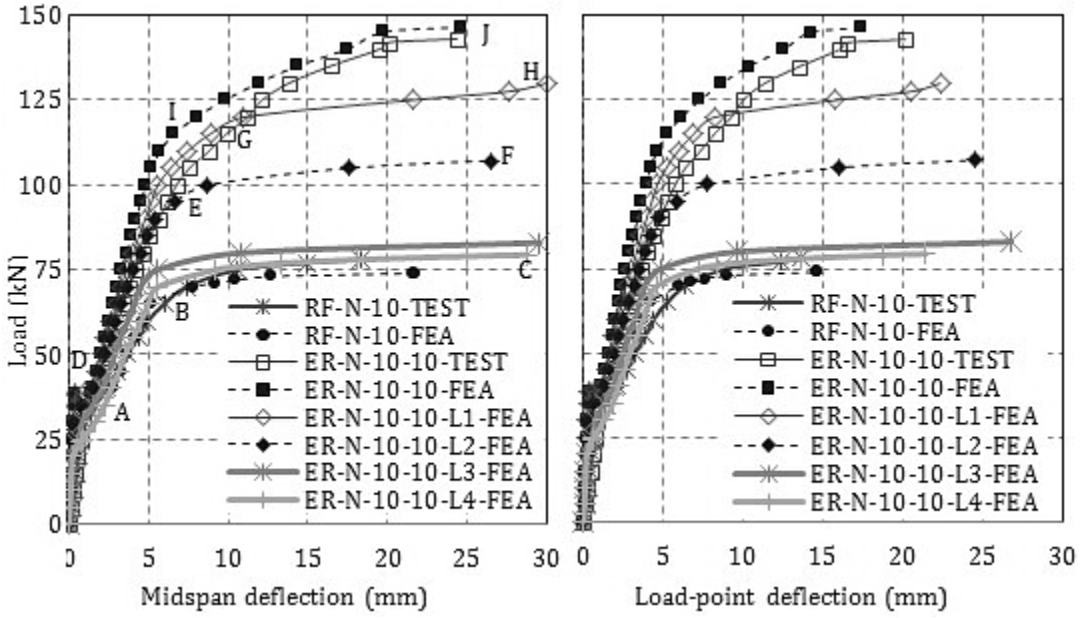

Fig. 3. Load versus deflection.

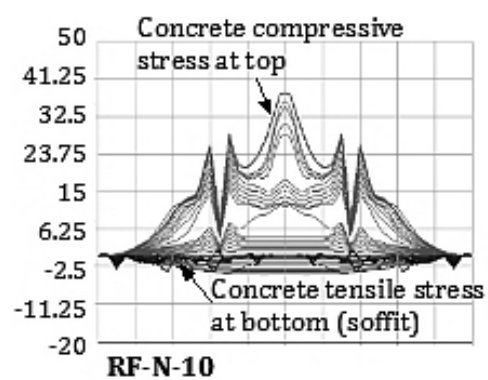

Stress reduction in concrete due steel plate at

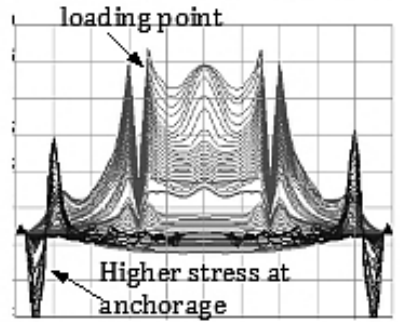

ER-N-10-10

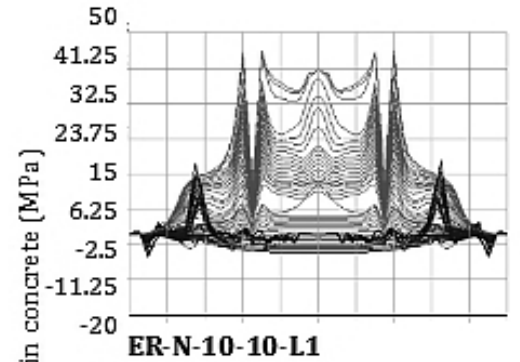

Stress reduction in concrete at

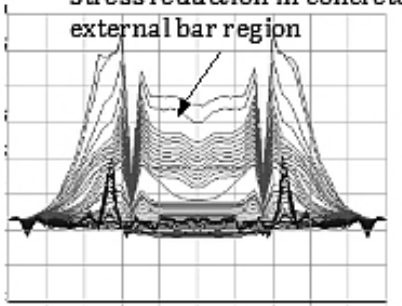

\section{ER-N-10-10-L2}

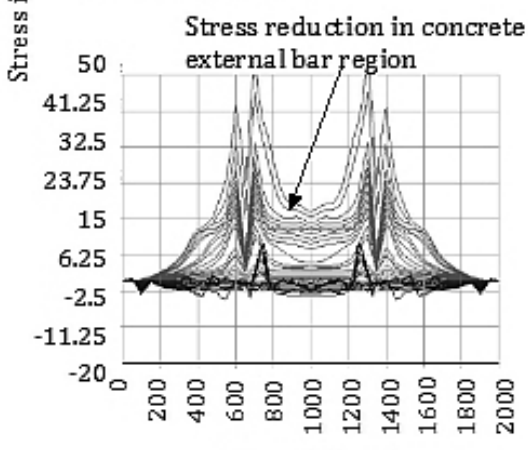

ER-N-10-10-L3

$$
\text { Length }(\mathrm{mm})
$$

Fig. 4. Stress distribution in concrete top (compression) and bottom (tension) surfaces. 
4.3. Stress Variation in Concrete along the Length of the Beam. Concrete surface stress variation along the length of the beam at top (compression) and bottom (tension) of beam at various loading stages, plotted by the program through APDL is depicted in Fig. 4. For the reference beam specimen (RF-N-10), the compressive stress variation along the span indicates four-point flexure behavior. It is to be noted that, at the loading point location, the concrete compressive stress is drastically reduced due to the provision of steel cushion plates. At the ultimate stage, after the yielding of internal bars, the midspan section of the beam experiences higher stress values close to the compressive strength of concrete. At the soffit of the beam, the tensile stress variation in concrete along the length of the span indicates pure flexure behavior. For the retrofitted beam specimen ER-N-10-10 with external bar length of $1650 \mathrm{~mm}$, the concrete stress variation along the length of the beam is uniform in the constant moment region. At the end anchorage locations of the external bars, local increase in concrete tensile stress is observed, which is higher for beam with larger external bar (ER-N-10-10) and gradually reduce with respect to length of external bar. This stress increase at the anchorage location leads to cracking of concrete at the anchorage locations. In all of the beam specimens (reference and retrofitted), at the loading point locations local reduction in stress is observed due to the provision of steel plates.
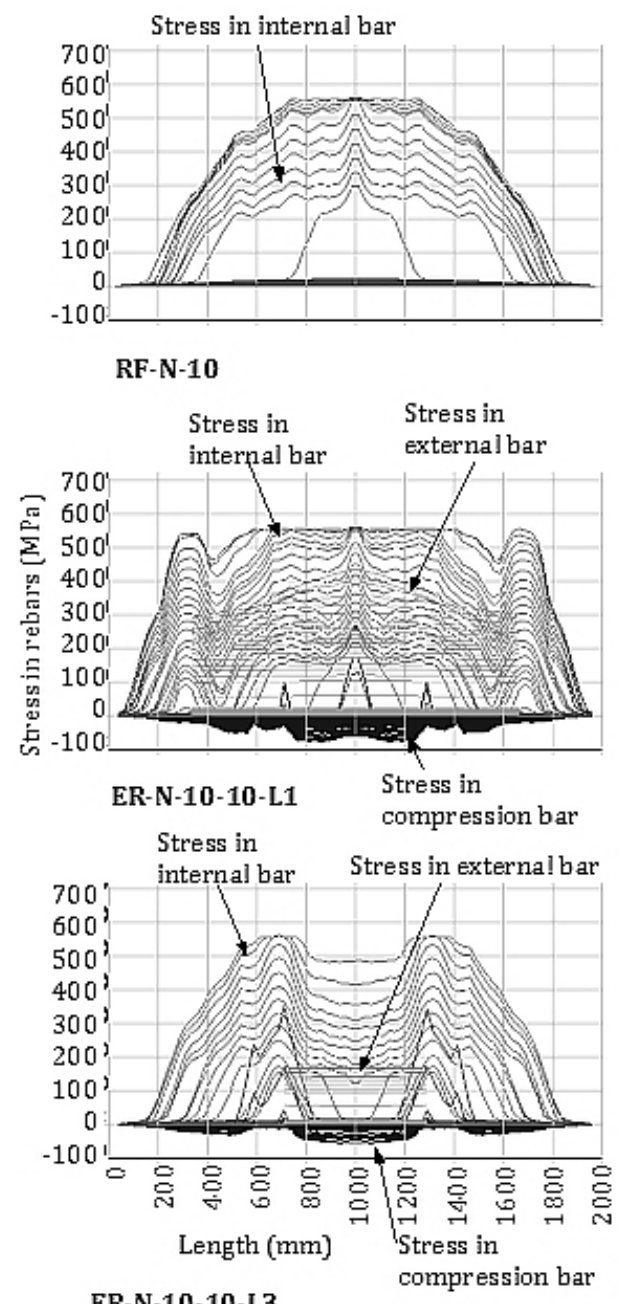
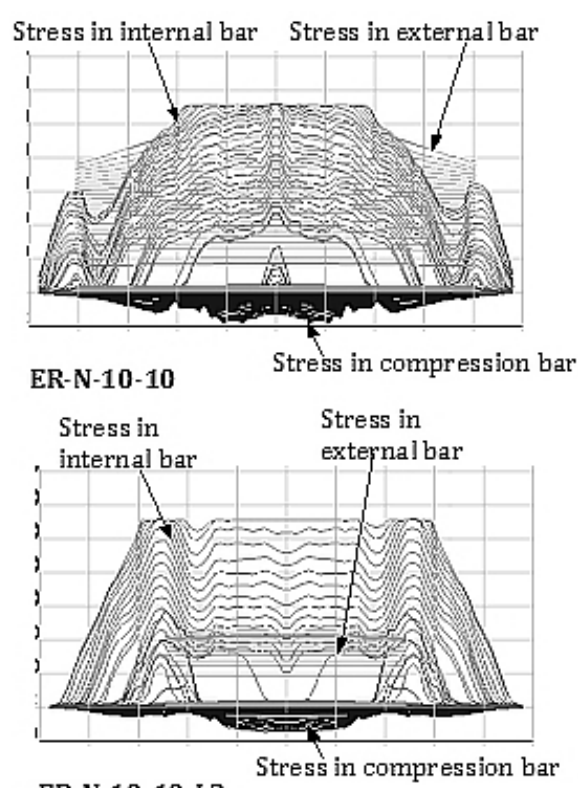

ER-N-10-10-L2

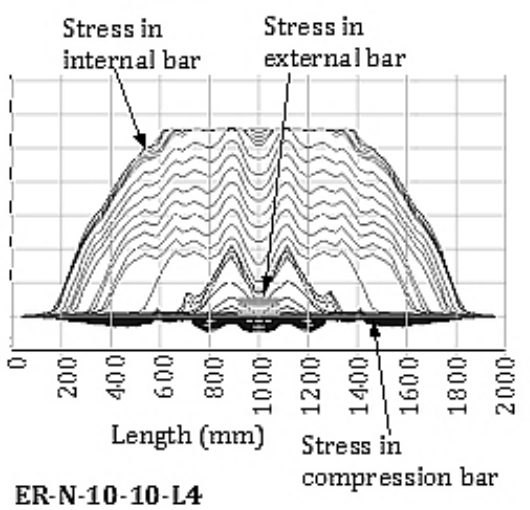

Fig. 5. Axial stress in internal, external, and compression bars. 
4.4. Steel Bar Stress Variation along the Length of the Beam. Stress in internal tension bar, compression bar and in the external bar at the soffit was extracted from the FE analysis through APDL and are depicted in Fig. 5. For the reference beam specimen (RF-N-10), stress variation in the internal tension bar clearly shows four-point bending behavior. The stress in internal bars varies along the length of the beam with zero at the supports to maximum at the midspan section of the beam with respect variation in bending moment. For retrofitted beam specimen ER-N-10-10 with lager external bar length of $1650 \mathrm{~mm}$, the stress in the internal bars shows a little variation when compared to the reference beam specimen. Stress in the external bar is uniform for the entire length of the bar till almost to the maximum loading level for all the retrofitted beam specimens. Only at ultimate load level, a slight variation in stress distribution is noted with maximum at the midspan location. Figure 5 clearly explains that, when the length of the external bar is larger (ER-N-10-10), then the maximum stress attained by the external bar is almost close to the tensile capacity of the steel bar. Whereas, when the length of the external bar is shorter (ER-N-10-10-L4), the maximum stress attainment is much less than the tensile capacity of the bar. Hence, it can be stated that, in order to achieve maximum benefit out of the external bar, the external bar shall be placed for the maximum length of the span. If the internal bar stress variation in specimen ER-N-10-10-L4 is compared with RF-N-10, the internal bar stress is variation is almost very similar, which shows no improvement in performance due to the provision of external bar of too shorter length.

4.5. Behavior at Initial Cracking, Internal Steel Yielding and Ultimate Stage. Load at initial cracking at anchorage location, midspan location, at yielding of internal steel and at ultimate stages were recorded and corresponding bending moment values were calculated for all the beam specimens and are tabulated in Table 3 and compared in Fig. 6. Crack patterns (zones) were generated for every $5 \mathrm{kN}$ load increment and few of the generated plots at critical stages are presented in Fig. $7 \mathrm{a}-\mathrm{f}$.

$\mathrm{T}$ a b 1 e 3

Comparison Moment at Critical Stages and Deflection Ductility Indices

\begin{tabular}{|c|c|c|c|c|c|c|c|}
\hline \multirow[t]{2}{*}{ No. } & \multirow[t]{2}{*}{ Beam ID } & \multirow{2}{*}{$\begin{array}{l}\text { Test/ } \\
\text { FEA }\end{array}$} & \multicolumn{4}{|c|}{ Moment $(\mathrm{kN} \cdot \mathrm{m})$ at } & \multirow{2}{*}{$\begin{array}{c}\text { Deflection } \\
\text { ductility } \\
\text { index } \\
\left(\delta_{u} / \delta_{y}\right)\end{array}$} \\
\hline & & & $\begin{array}{c}\text { Initial crack } \\
\text { at anchorage } \\
\text { of external } \\
\text { bars }\end{array}$ & $\begin{array}{l}\text { Initial } \\
\text { flexural } \\
\text { crack at } \\
\text { midspan }\end{array}$ & $\begin{array}{c}\text { Yielding } \\
\text { of internal } \\
\text { steel }\end{array}$ & $\begin{array}{l}\text { Ultimate } \\
\text { stage }\end{array}$ & \\
\hline \multirow[t]{2}{*}{1} & \multirow[t]{2}{*}{ RF-N-10 } & Test & - & 8.0 & 17.9 & 21.5 & 3.07 \\
\hline & & FEA & - & 9.7 & 17.9 & 20.4 & 4.24 \\
\hline \multirow[t]{2}{*}{2} & \multirow[t]{2}{*}{ ER-N-10-10 } & Test & 11.1 & 10.7 & 27.5 & 39.3 & 3.60 \\
\hline & & FEA & 10.6 & 10.6 & 31.6 & 40.3 & 3.73 \\
\hline 3 & ER-N-10-10-L1 & FEA & 10.5 & 10.7 & 30.3 & 35.8 & 4.02 \\
\hline 4 & ER-N-10-10-L2 & FEA & 7.7 & 10.6 & 24.8 & 29.5 & 4.86 \\
\hline 5 & ER-N-10-10-L3 & FEA & 6.6 & $9.7^{*}$ & 20.6 & 22.8 & 5.32 \\
\hline 6 & ER-N-10-10-L4 & FEA & 6.7 & $9.7^{*}$ & 19.3 & 21.8 & 5.14 \\
\hline
\end{tabular}

* See details in Subsections 4.5.5 and 4.5.6. 


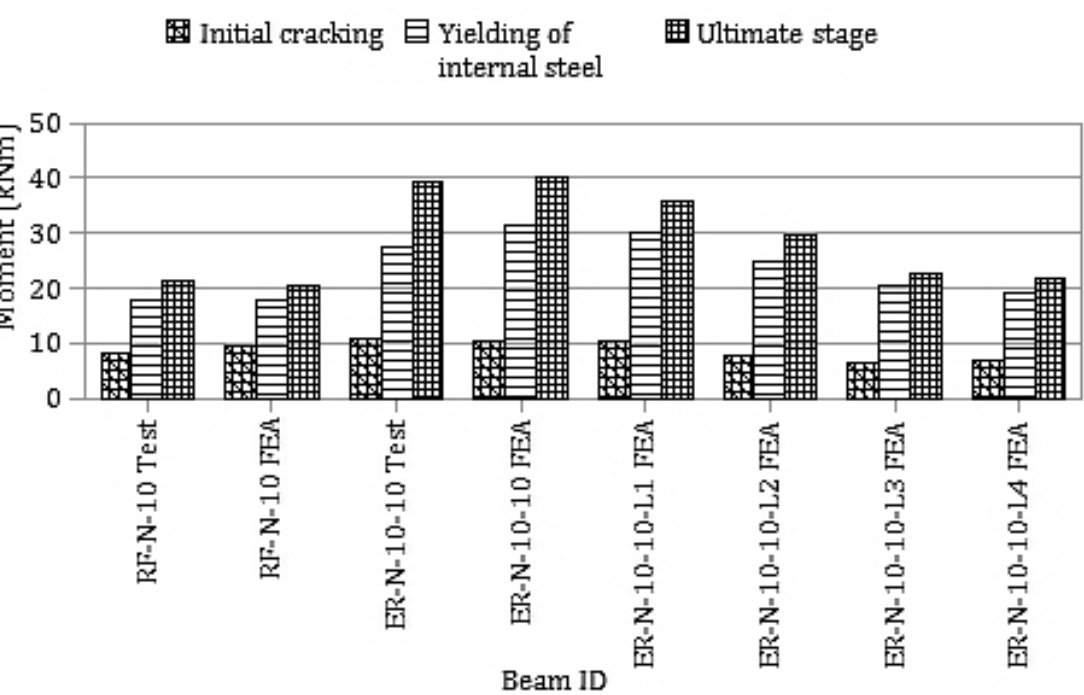

Fig. 6. Comparison of moment at critical stages.

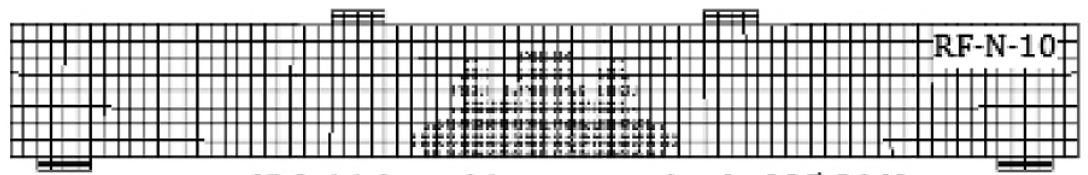

(i) Initial cracking zone at load of $35.3 \mathrm{kN}$

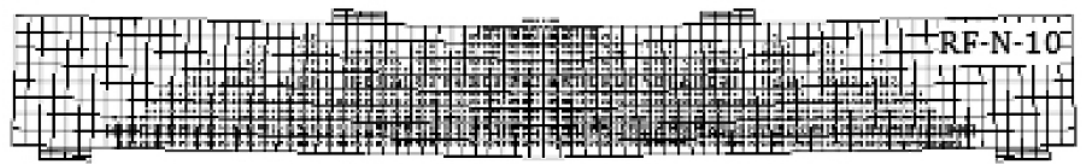

(ii) Ultimate cracking zone at load of $74.15 \mathrm{kN}$

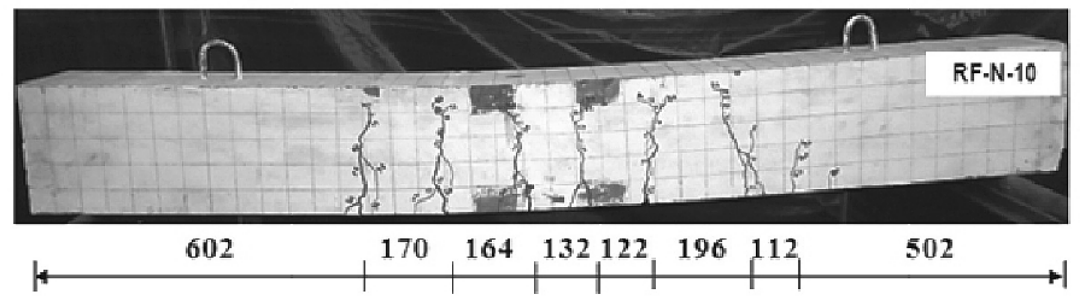

Fig. 7a. Reference beam: RF-N-10.

4.5.1. Reference Beam Specimen: $R F-N-10$. It is to be noted that for the conventional beams (without external bars) the load at first crack essentially depends upon the strength of concrete. The FEA results obtained at initial cracking stage, yielding of internal steel and ultimate stages are in order with the experimental results. The cracking zones were originated at midspan and propagated towards the supports as shown in Fig. 7a.

4.5.2. Retrofitted Beam Specimen: ER-N-10-10 (External Bar Length: $1650 \mathrm{~mm}$ ). It was observed by the earlier studies of the authors $[2,9,10]$ that the provision of external bars with maximum length of $1650 \mathrm{~mm}$ (almost equal to the span) for specimen ER-N-10-10 has significantly contributed in enhancing the load at initial crack formation. It is also observed that the cracking at anchorage location of the external bar and at the midspan occurred simultaneously (Fig. 7b). 


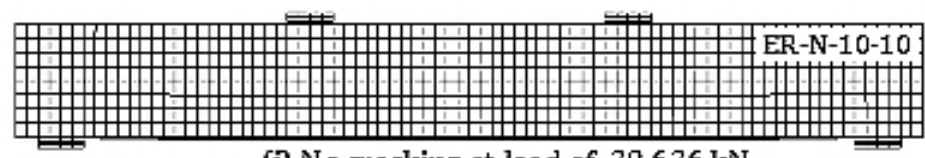

(i) No cracking at load of $38.636 \mathrm{kN}$

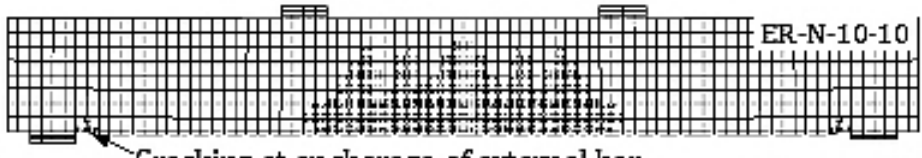

Cracking at anchorage of external bar

fiil In itial cracking zone at load of $38.637 \mathrm{kN}$

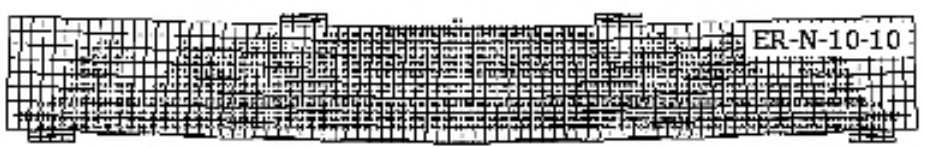

(iii) Ultimate cracking zone at load of $146.5 \mathrm{kN}$

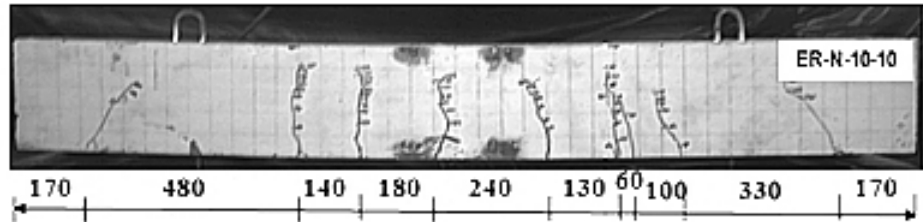

Fig. 7b. Retrofitted beam: ER-N-10-10.

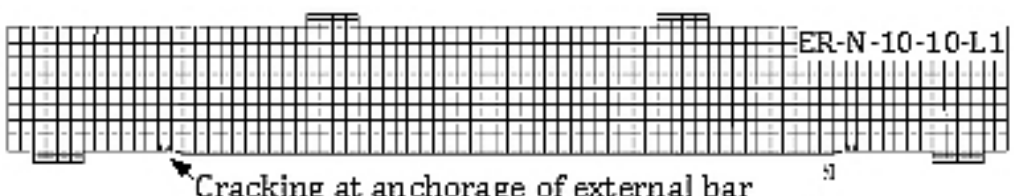

(i) Initial cracking at anchorage of external bar at load of $38.281 \mathrm{kN}$

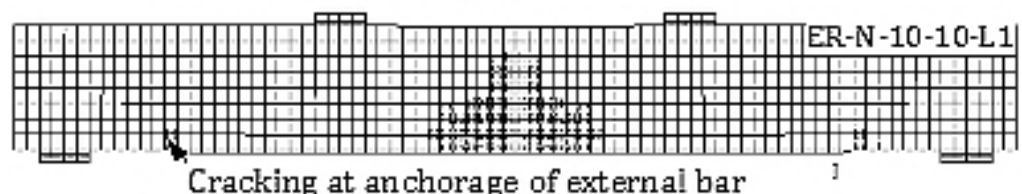

(ii) Cracking at anchorage and flexural zone at load of $38.808 \mathrm{kN}$

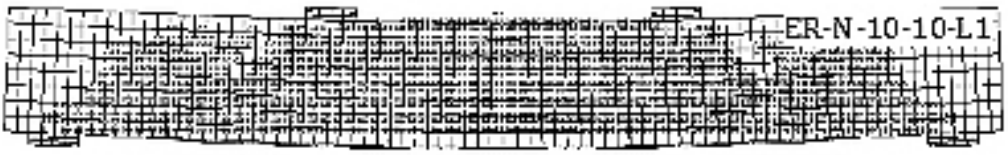

(iii) Ultimate cracking zone at load of $130 \mathrm{kN}$

Fig. 7c. Retrofitted beam: ER-N-10-10-L1.

4.5.3. Retrofitted Beam Specimen: ER-N-10-10-L1 (External Bar Length: $1350 \mathrm{~mm}$ ). For retrofitted beam specimen ER-N-10-10-L1 (with $1350 \mathrm{~mm}$ external bar length) initial cracking moment capacity is almost same as that of ER-N-10-10. It is to be noted that the moment at initial cracking at anchorage location of the external bar is marginally less than at the midspan location. Crack pattern simultaneously propagates from midspan and from anchorage points of the external bars (Fig. 7c). 


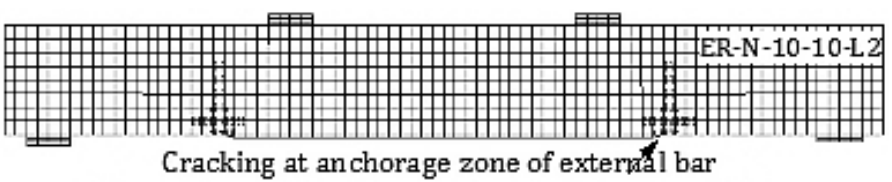

(i) Initial cracking at an chorage of external bar at

load of $28.13 \mathrm{kN}$

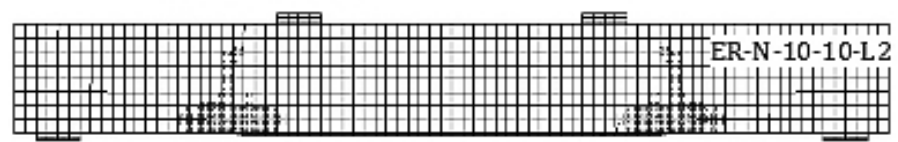

(ii) Cracking zone at anchorage of external bar at load of $35 \mathrm{kN}$

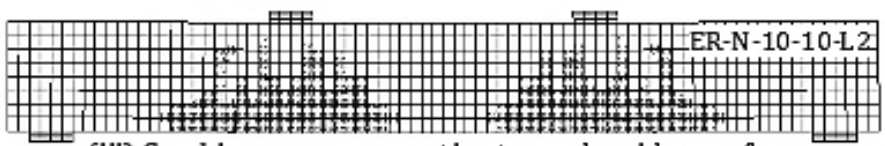

(iii) Cradking zone propagating towards mid-span from anchorage of external bar at load of $40 \mathrm{kN}$

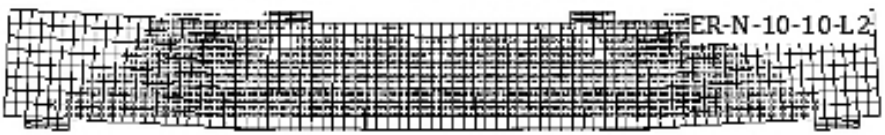

(iv) Ultimate cracking zone at load of $107.2 \mathrm{kN}$

Fig. 7d. Retrofitted beam: ER-N-10-10-L2.

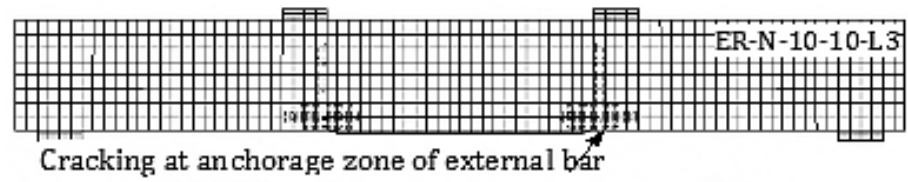

(i) Initial cracking at anchorage of external bar at load of $23.899 \mathrm{kN}$

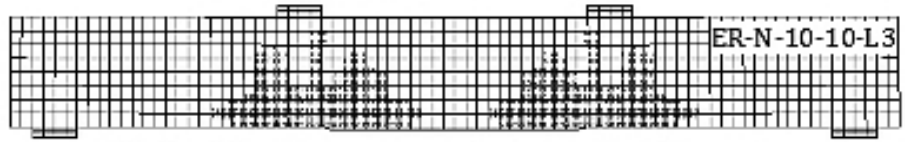

(ii) Cracking zone propagating towards mid-span from anchorage of external bar at load of $35 \mathrm{kN}$

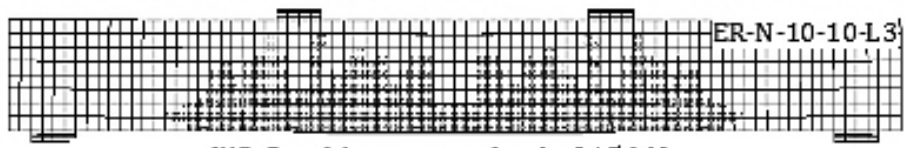

(iii) Cracking zone at load of $45 \mathrm{kN}$

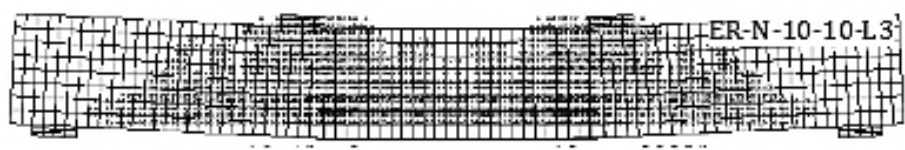

(iv) Ultimate cracking zone at load of $83 \mathrm{kN}$

Fig. 7e. Retrofitted beam: ER-N-10-10-L3.

4.5.4. Retrofitted Beam Specimen: ER-N-10-10-L2 (External Bar Length: $1000 \mathrm{~mm}$ ). The specimen ER-N-10-10-L2 with external bar length of $1000 \mathrm{~mm}$, the initial cracking moment at anchorage location $(7.7 \mathrm{kN} \cdot \mathrm{m})$ is considerably less than at midspan location $(10.6 \mathrm{kN} \cdot \mathrm{m})$. Hence, the initial cracking performance is controlled by the anchorage of the external bar, which minimizes the overall performance at the initial cracking stage when 


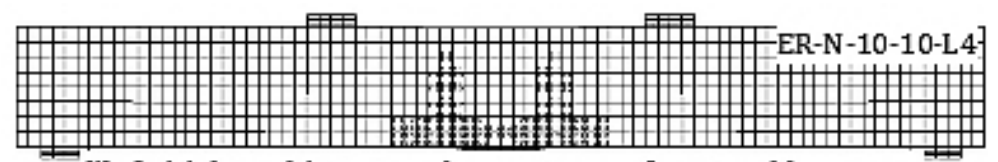

(i) Initial cracking at an chorage zone of external bar at load of $25 \mathrm{kN}$

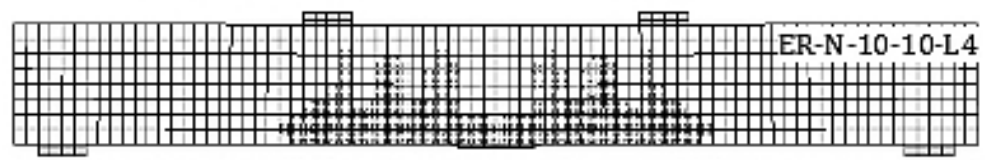

(ii) Cracking zone at load of $30 \mathrm{kN}$

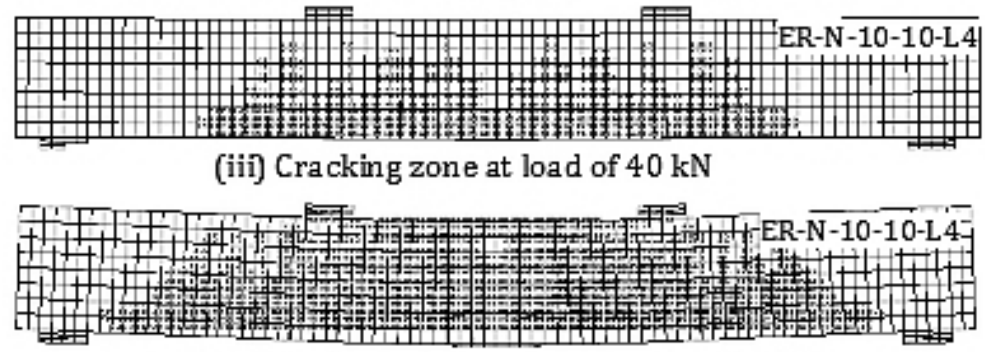

(iv) Ultimate cracking zone at load of $79.4 \mathrm{kN}$

Fig. 7f. Retrofitted beam: ER-N-10-10-L4.

compared to the reference beam specimen in spite of retrofitting with external bar. The performance at yielding of internal bar $(24.8 \mathrm{kN} \cdot \mathrm{m})$ and at ultimate stage $(29.5 \mathrm{kN} \cdot \mathrm{m})$ is also considerably reduced with respect to ER-N-10-10 and ER-N-10-10-L1 (Fig. 7d).

4.5.5. Retrofitted Beam Specimen: ER-N-10-10-L3 (External Bar Length: $600 \mathrm{~mm}$ ). For beam specimen ER-N-10-10-L3, the initial cracking starts at anchorage location of the external bar with considerably lower moment $(6.6 \mathrm{kN} \cdot \mathrm{m})$ than the reference beam $(9.7 \mathrm{kN} \cdot \mathrm{m})$ specimen and propagating towards the midspan. Hence, provision of external bar of shorter length considerably reduces the initial cracking moment even when compared to the reference beam specimen. However, the performance at the yielding of internal bar and at the ultimate stage is marginally higher than the reference beam specimen, but considerably less than the ER-N-10-10, ER-N-10-10-L1, and ER-N-10-10-L2 (Fig. 7e).

4.5.6. Retrofitted Beam Specimen: ER-N-10-10-L4 (External Bar Length: $200 \mathrm{~mm}$ ). For beam specimen ER-N-10-10-L4, the initial cracking starts at anchorage location of the external bar at considerably lower moment $(6.7 \mathrm{kN} \cdot \mathrm{m})$ than the reference beam $(9.7 \mathrm{kN} \cdot \mathrm{m})$ specimen and propagates towards the midspan and supports. Hence, provision of external bar of shorter length plays a negative role in controlling the initial cracking behavior even when compared to the reference beam specimen. Also, the performance at the yielding of internal bar $(19.3 \mathrm{kN} \cdot \mathrm{m})$ and at the ultimate stage $(21.8 \mathrm{kN} \cdot \mathrm{m})$ is almost same as that of reference beam specimen, but considerably less than the ER-N-10-10, ER-N-10-10-L1, ER-N-10-10-L2, and ER-N-10-10-L3 (Fig. 7f).

The above discussion clearly indicates that the proposed external reinforcement technique is effective only when the length of the external bar is almost same as that of the span of the beam. Also, when the length of the external bar is considerably shorter than the span, it produces negative impact in controlling the initial cracking behavior due to premature cracking at anchorage location.

4.6. Deflection Ductility. Ductility indices were calculated using the load versus midspan deflection curves using $\mu_{\delta}=\delta_{u} / \delta_{y}\left[\delta_{u}\right.$ is the midspan deflection at ultimate load (mm) and $\delta_{y}$ is the midspan deflection at yielding of internal tension steel (mm)] and 
are furnished in Table 3. It is observed that all the retrofitted beam specimens shows improvement in ductility performances when compared to the reference beam specimen. It is interesting to note that, the ductility performances are improved with respect decrease in length of external bars. This is the only advantage seen from the study with respect to reduction in length of external bar.

Conclusions. Based on the finite element analysis conducted to study the effect of length of external bars on the performance of retrofitted $\mathrm{RC}$ beams the following conclusions are made:

1. The moment carrying capacity of the retrofitted beam specimen ER-N-10-10 with maximum external bar length of $1650 \mathrm{~mm}$ (almost same as the span of beam) increases by nearly 75 and $95 \%$ when compared to the reference beam specimen RF-N-10 at yielding of internal steel and at ultimate stage respectively.

2 . The moment carrying capacity of the retrofitted beam specimens gradually reduces with reduction in the length of external bar (from 1650 to $200 \mathrm{~mm}$ ).

3. Provision of external bar of too shorter length, reduces the initial cracking moment even less than the reference beam section, due to premature cracks at the anchorage location of the external bars.

4. The only positive aspect noted by the study is that, improvement in the ductility performance in deflection with respect decrease in length of external bars.

5. In general, the provision of external bar of length too shorter than the span has not shown any improvement in behavior due to loss of tied-arch action of external bars at soffit and hence not recommended. Hence, it is recommended to provide external bar of longer length (covering almost for the entire span length) in order to achieve tied-arch action for the effective performance.

\section{Р е 3 юм е}

Наведено результати скінченноелементного розрахунку прогину модифікованого залізобетонного перекриття з урахуванням впливу довжини зовнішнього стельового бруса. За допомогою програмного пакета ANSYS 12.0 розраховано напруженодеформований стан п’яти зразків модифікованого залізобетонного перекриття, підсиленого зовнішнім брусом різної довжини, і тарувального зразка. Досліджено процеси зародження тріщин, поведінку перекриттів за пластичної деформації внутрішнього бруса і на стадії руйнування, а також закономірності формування і розповсюдження тріщин.

1. S. Kothandaraman and G. Vasudevan, "Flexural retrofitting of RC beams using external bars at soffit level - an experimental study," Constr. Build. Mater., 24, No. 11, 2208-2216 (2010).

2. G. Vasudevan and S. Kothandaraman, "Experimental investigation on the performance of RC beams strengthened with external bars at soffit," Mater. Struct., 47, No. 10, 1617-1631 (2014).

3. L. Dahmani, A. Khennane, and S. Kaci, "Crack identification in reinforced concrete beams using ANSYS software," Strength Mater., 42, No. 2, 232-240 (2010).

4. R. A. Hawileh, M. Z. Naser, and J. A. Abdalla, "Finite element simulation of reinforced concrete beams externally strengthened with short-length CFRP plates," Compos. Part B - Eng., 45, No. 1, 1722-1730 (2013).

5. M. L. Bennegadi, Z. Sereir, and S. Amziane, "3D nonlinear finite element model for the volume optimization of a RC beam externally reinforced with a HFRP plate," Constr. Build. Mater., 38, 1152-1160 (2013). 
6. R. A. Rousan and R. Haddad, "NLFEA sulfate-damage reinforced concrete beams strengthened with FRP composites," Compos. Struct., 96, 433-445 (2013).

7. M. Aktas and Y. Sumer, "Nonlinear finite element analysis of damaged and strengthened reinforced concrete beams," J. Civ. Eng. Manag., 20, No. 2, 201-210 (2014).

8. A. M. Sayed, X. Wang, and Z. Wu, "Finite element modeling of the shear capacity of RC beams strengthened with FRP sheets by considering different failure modes," Constr. Build. Mater., 59, 169-179 (2014).

9. G. Vasudevan and S. Kothandaraman, "Finite element analysis of bearing capacity of RC beams retrofitted with external bars," Strength Mater., 46, No. 6, 831-842 (2014).

10. G. Vasudevan and S. Kothandaraman, "RC beams retrofitted using external bars with additional anchorages - a finite element study," Comput. Concrete, 16, No. 3, 415-428 (2015).

11. M. B. Zidani, K. Belakhdar, A. Tounsi, and E. A. A. Bedia, "Finite element analysis of initially damaged beams repaired with FRP plates," Compos. Struct., 134, 429-439 (2015).

12. G. M. Chen, J. G. Teng, J. F. Chen, and Q. G. Xiao, "Finite element modeling of debonding failures in FRP-strengthened RC beams: A dynamic approach," Comput. Struct., 158, 167-183 (2015).

13. B. Almassri, F. A. Mahmoud, and R. Francois, "Behaviour of corroded reinforced concrete beams repaired with NSM CFRP rods, experimental and finite element study," Compos. Part B - Eng., 92, 477-488 (2016).

14. J. G. Teng, S. S. Zhang, and J. F. Chen, "Strength model for end cover separation failure in RC beams strengthened with near-surface mounted (NSM) FRP strips," Eng. Struct., 110, 222-232 (2016).

15. P. Pathak, Y. X. Zhang, and X. Teng, "Nonlinear finite element analysis of FRP strengthened RC beams with bond-slip effect," Int. J. Comput. Methods, 14, 1750032 (2017), DOI: 10.1142/S0219876217500323.

16. IS 456 (2000): Plain and Reinforced Concrete - Code of Practice, Bureau of Indian Standards, New Delhi (2000). 